\title{
AN ANALYSIS OF THE UTILIZING ZOOM APPLICATION TO ENGLISH LEARNERS' SPEAKING SKILL MOTIVATION
}

\author{
Sabila Nur Risma ${ }^{1}$ \\ ${ }^{1}$ IKIP Siliwangi \\ ${ }^{1}$ sabilsabilanr@gmail.com
}

\begin{abstract}
Speaking is one of the productive skills that should be learned and mastered by English learners which gives them the ability to communicate effectively in this global world. However, most learners face difficulties in learning English, especially in mastering speaking skills. The lack of motivation in learning English is the most common problem faced by learners. With the development of technology, employing Zoom Application in learning English is recommended for fun and exciting learning. This research aims to analyze how applying Zoom Application can improve English learners' motivation to speak in English. The descriptive qualitative method is used in this research and to gain the data, the researcher used some instruments, there are questionnaires and interviews, which were carried out to 30 learners in English Zoom Club as subjects of the research. The result of this research suggested that applying Zoom Application is very interesting since it provides such motivating and stimulating activities for English learners. Moreover, using Zoom Application make English learners have an appropriate platform and new friends to practice improving their speaking skill at the same time.
\end{abstract}

Keywords: Speaking Skill, Motivation in Language Learning, Zoom Application

\section{INTRODUCTION}

In this modern era, most people throughout the world learn English because English has an important role in many aspects. This situation leads to the need for English learners on improving their communication skills which play a vital role that should be mastered by them. According to Cameron (2005), speaking is used to express meanings so that other people can make sense of them. In other words, speaking is the most important skill to communicate well in this global era. Even though speaking skill is important, most of the learners are reluctant to speak up, have no interlocutors or even they have no platform so they have low motivation. It is supported by Nunan (1993) he mentions that there are some challenges in learning an oral skill namely lack of motivation.

Since the traditional methods have become less motivated, today, the technological innovations in learning language are being used as to learners' motivation. The learners of English are easy to access a wide range of resources in terms of communication with others by technology. From the early days, varieties of software and applications, there has been discussion of how technologies can play a role in motivating learners in learning a language (Warschauer,1996) and as technologies have become more sophisticated, the growing range of uses of technology increases the potential for enhanced motivation. To make the learning process as comfortable and effective as possible, most of the learners choose the properly selected digital tools for learning.

Today, there are so many tools, methods and platforms to be used for online learning. Among the online media applications which are usually used for video conferences. Zoom Application comes with a cloud platform for video, audio, collaboration, chat, and webinars as the 
technological innovations in learning a language which makes it very easy for learners to learn language through access from various gadgets such as PC, laptop, android phone, iPhone and tablet. Referring to these theories of experts and phenomena, this research focused on the analysis of utilizing Zoom Application to English learners' speaking skill motivation.

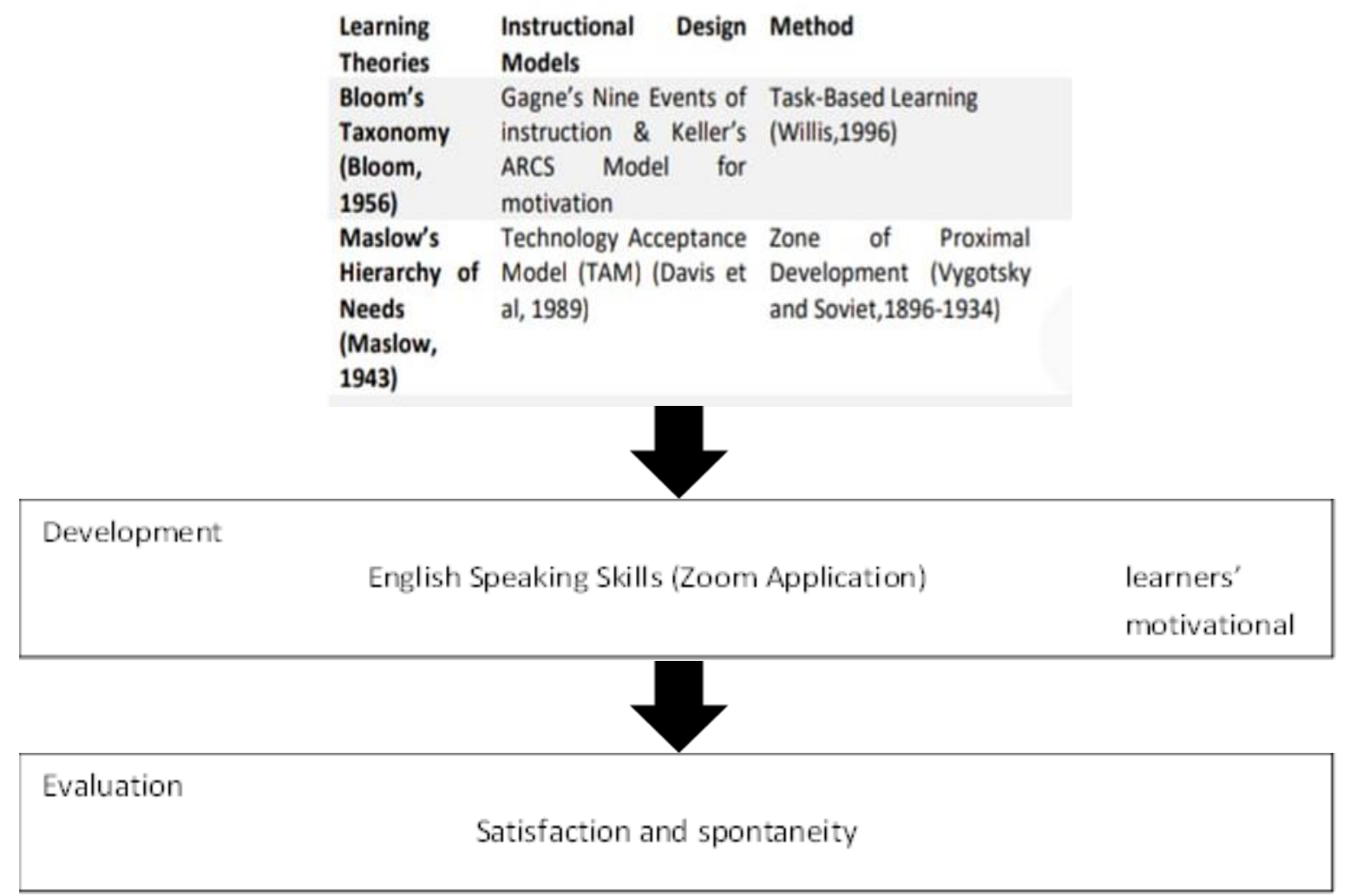

Figure 1. The Framework of Learning Theories with Technological Integration

\section{Speaking Skill}

Speaking is Speaking is the heart of every foreign language learning. It is known as the verbal productive skill to communicate thoughts, messages, information, and feelings. Being able to talk with the target language is the output of learning speaking. It is supported by Harris (1974), he states that speaking as the process whereby we communicate our ideas, thought, and feelings orally. In speaking, people can express themselves to other people to tell what they need and to fulfill what other people ask and they can understand also make connections with each other.

Brown (2001) says that speaking is an interactive process of constructing meaning that involves, producing, receiving, and processing information. To construct the meaning during the interaction among the participants of communication (speakers and listeners), there is a point that must be occurring which is becoming a speaker who produces a message and the other become listener who receive messages. In this case, the speaking process or communication needs at least two people because we cannot do it individually. Relating to this, a transactional dialogue is suitable to improve learners' speaking achievements since transactional dialogue refers to a situation where the focus is on what is said or done. The message and making oneself understood clearly and accurately is the central focus, also how they interact socially with each other (Jones, 1996). 


\section{Motivation in Language Learning}

Hammer in Marsono (2005) mentions that motivation is some kind of internal drive that encourages somebody to pursue action. In this case, learners should be motivated in such a way that they should enjoy, active, and protected from being embarrassed, fear of making mistakes, and anxious in learning language activities. They should feel they study the real language.

According to Chuan and Dornyei (2007), motivation is one major key factor in determining the success or failure in foreign language learning. The learners need to involve in English speaking activities require a certain level of motivation. In general, motivation divides into intrinsic and extrinsic factors that stimulate energy and yearning in learners to be continually interested to learn and engaging in English activities.

Furthermore, Elsa et all (2016), states that intrinsic motivation is an action taken for satisfaction one advantage of engaging in the ability itself. By contrast, extrinsic motivation refers to the need for achievement to get certain rewards (Pittman and Bogiano, 1992, as cited in Mat and Yunus, 2014). However, research conducted by Mat and Yunus (2014) suggests that learners are usually motivated, have a positive attitude towards learning English as long as it is given extrinsically although it does not need to be interpreted as a complementary effort to improve proficiency.

Several kinds of research state in Saputra's study (2017) that there is an important relationship between motivation and learning because motivation maintains learners for longer study time, so it can make the best result. Yet, it very depends on how the learning environment and tools support their motivation for learning a language. Have interlocutors and a good tool or platform in this global era is very crucial to stimulate motivation because learners mostly learn by using technology so it will help them understand correctly and efficiently which eliminated bad emotions such as fear, anxiety and lack of motivation to learn.

\section{Zoom Application}

In this challenging modern era of technology (web 2.0), learners are delighted to learn using the basic concept of technology. They are also beneficial by this technology because it could help them in learning the language easily with a more flexible time and place. According to Stockwell (2016), he mentions that technology plays an important role in bringing innovation and motivation for the learners. Online learning includes the use of devices such as computers and mobile phones set great instructional environments which will help learners to save travel time and costs to traditional face-to-face learning.

Through the well-known online communication media like Zoom Application, online language learning getting more popular as one of the learning methods which can answer the problematic condition is the use of online communication media. Zoom is a communication application using video and can be used in a variety of mobile devices, desktops, telephone, and space systems. In general, users who use this application to conduct meetings to video and audio conferences. The application which is headquartered in San Jose California, United States was founded in 2011 and is used by various organizations and companies to accommodate employees remotely or used in the learning process.

Web 2.0 tools and motivation has been studied extensively. Terrell (2011) says that access to online tools increases English language learners' motivation to practice English outside the classroom. Mcloughlin and Lee (2008) argue that web 2.0 tools such as Zoom Application appear to motivate the individual to link personal interests and as a communication solution product to broader social networks and participating. Thus, in a dynamic community that provides feedback. 


\section{METHOD}

The descriptive qualitative method is used in this research to analyze the speaking skill motivation through Zoom Application. The descriptive qualitative approach is used for this research because through this approach the complex behaviors and experiences of the individual learners can be examined and understood well. It is based on the research focus to analyze the utilizing of Zoom Application in the practice of English speaking skill on English Zoom Club conducted from 31st October until 28th November 2020. Bodgan and Biklen (in Sugiyono, 2010:9) mention that qualitative research has some characteristics as follows:

1. Qualitative research is descriptive. The data collected is in the form of words of pictures rather than the number.

2. Qualitative research is concerned with the process rather than simply with outcomes or products.

3. Qualitative research tends to analyze their data inductively.

4. Qualitative research has the natural setting as the direct source of data and the researcher is the key instrument.

5. "Meaning" is essential to qualitative research.

A survey research design by using questionnaire and interview were employed by the researcher to conduct this research. Questionnaire survey is one of the most common methods of data collection, it can also act as a very useful tool for researchers to gather a good deal of information in a short time with little cost (Dörnyei \& Taguchi (2010); Dornyei (2003, cited in McKay 2006), cited in Ahmed, 2015). Meanwhile, Ehrenberg (in Sugiono, 2010:231) mentions that an interview is a meeting of two persons to exchange information and idea through questions and responses, resulting in communication and joint construction of meaning about a particular topic.

The participants of this research were 30 English learners of various circles who were joined to English Zoom Club. Questionnaire and interviews were then distributed to 30 English learners. It implied learners' opinion toward speaking motivation when they learn English speaking with Zoom Application.

\section{RESULTS AND DISCUSSION}

\section{Results}

In obtaining the information, the researcher asks questions through questionnaires and interviews. Here is a description of the questionnaires and interviews with 30 English learners of the English Zoom Club. Data of utilizing of Zoom Application used in learning practice of speaking skill activities are described as follows:

First, third, fifth, seventh, and ninth session (October $31^{\text {st }}$ - November $28^{\text {th }}, 2020$ ).

In the first activity, at the first until ninth session or meeting of the speaking activity, the researcher focused on the introduction of the English Zoom Club method and the purpose of English Zoom Club in learning practice English speaking skill to the English learners from various circles or everyone who wants to join. This section will be prepared 90 minutes before the meeting start. Rizal Taufiq (IKIP Siliwangi student) as the instructor and founder of English Zoom Club will share the program schedule and the access link to the Zoom meeting in the WhatsApp group that was available in this process of speaking exercise. 


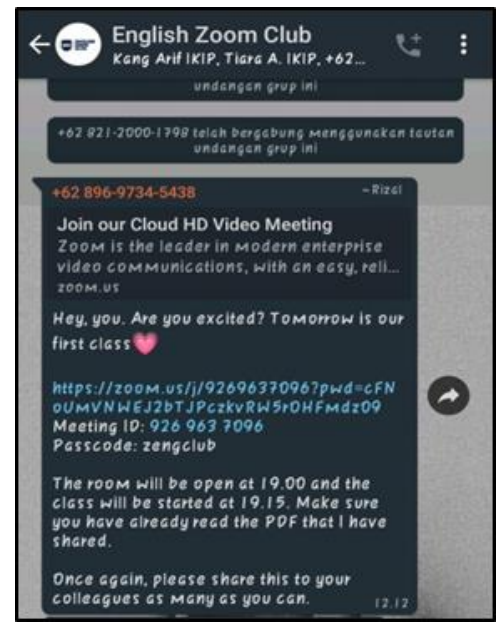

Picture 1. The Access Link to The Zoom Meeting

In the second activity, the instructor will share the powerpoint which contains the rules and the topics that will be discussed in each session.

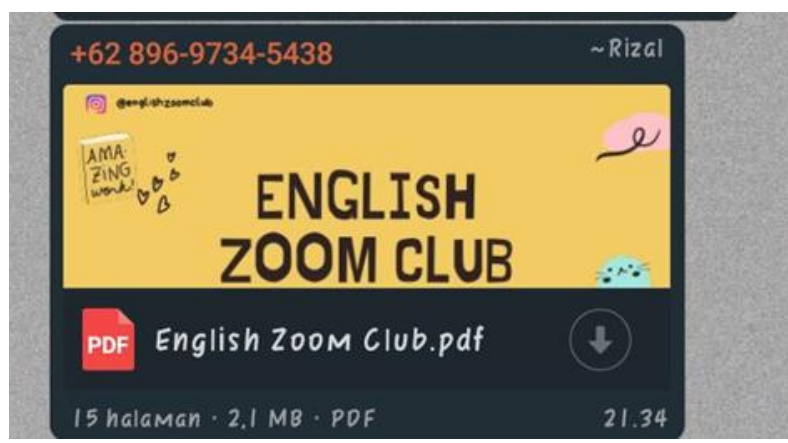

Picture 2. The PowerPoint Which Contains The Activity

In the third activity, the instructor begins to start opening the meeting room as a host. It starts with a greeting and begins with introducing English Zoom Club and then share the PowerPoint on the Zoom screen and explains the method of practice speaking skill with this Zoom Application.
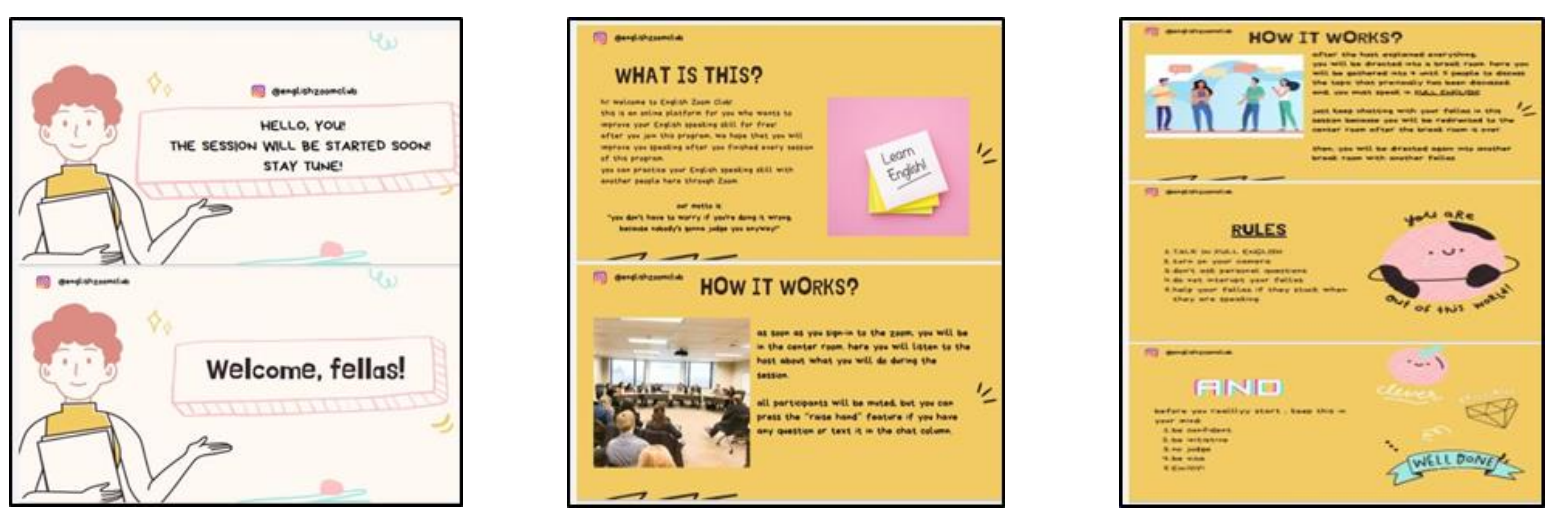

Picture 3. Zoom Screen The Activity's Method

Fourth activity, the instructor divides the participants who join into the breakout room Zoom which contains 3-4 people randomly three times with different topics about 15-20 minutes to speak up using full English language with other participants in breakout room Zoom starting 
by getting acquainted with each other. In this activity, communication between participants or English learners occurred.

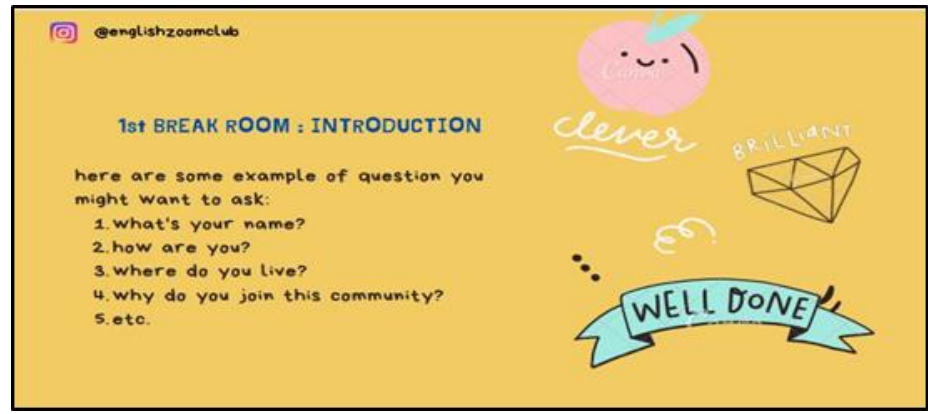

Picture 4. Break room Zoom activity

Table 1. Online Practice Speaking Schedule

\begin{tabular}{|c|c|c|c|}
\hline Date & Session & Time & Activity \\
\hline 31 October 2020 & First session & $\begin{array}{c}19.45 \text { p.m. }-22.30 \\
\text { p.m. }\end{array}$ & $\begin{array}{l}\text { 1) Introduction } \\
\text { speaking practice }\end{array}$ \\
\hline 07 November 2020 & Third session & $\begin{array}{c}19.30 \text { p.m. }-22.00 \\
\text { p.m. }\end{array}$ & $\begin{array}{l}\text { procedure } \\
\text { 2) Break room Zoom }\end{array}$ \\
\hline 14 November 2020 & Fifth session & $\begin{array}{l}19.15 \text { p.m. - } 22.15 \\
\text { p.m. }\end{array}$ & $\begin{array}{l}\text { I: Introduction } \\
\text { 3) Break room Zoom }\end{array}$ \\
\hline 21 November 2020 & Seventh session & $\begin{array}{c}19.45 \text { p.m. }-22.15 \\
\text { p.m. }\end{array}$ & $\begin{array}{c}\text { II: Topic } 1 \\
\text { 4) Break room Zoom }\end{array}$ \\
\hline 28 November 2020 & Ninth session & $\begin{array}{l}19.30 \text { p.m.- } 22.15 \\
\text { p.m. }\end{array}$ & $\begin{array}{l}\text { III: Topic } 2 \\
\text { 5) Break room Zoom } \\
\text { IV: Topic } 3\end{array}$ \\
\hline
\end{tabular}

The fifth activity, this is the last activity on the first meeting is reviews from the instructor and then the instructor will take a photo through the zoom screen capture feature of the participants who take part in English speaking practice. The practice will be continued at the next meeting. The last is the instructor say greeting to all participants.

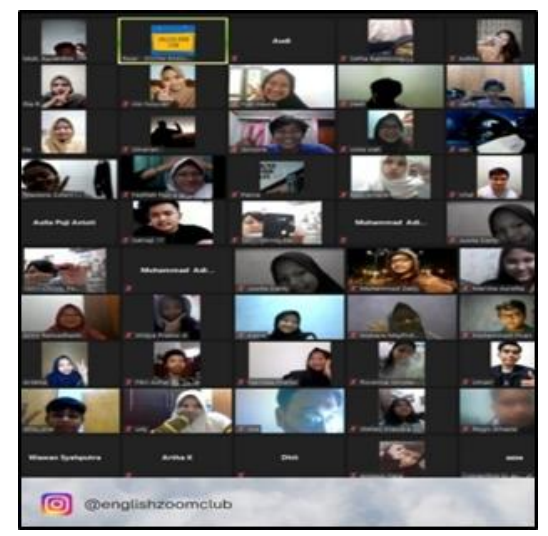

Picture 5. Screen Capture Session

Here is a description of the results of the questionnaires with 30 students by applying Dichotomous questions which are usually used in a survey that asks for Yes/No answers. It is used for a clear distinction of qualities, experiences, or respondent's opinions. The data can be reported as follows: 


\section{1) Questionnaire $\bigcirc$ Yes \\ No}

Question 1: "So far, have you felt that your English speaking skills are lacking?"

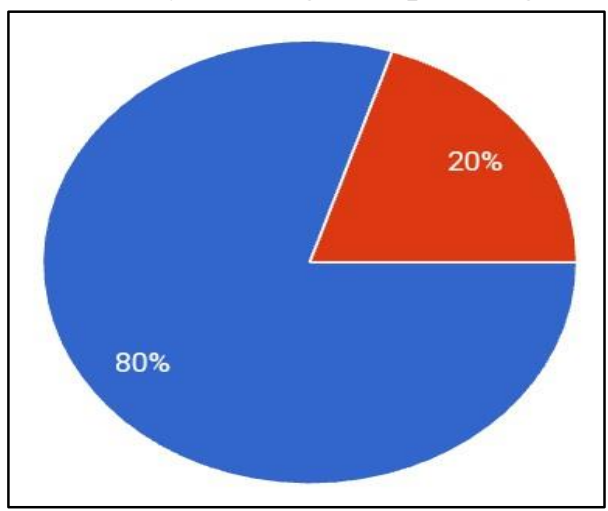

$80 \%$ of 30 English learners said that they felt they could not speak English.

Question 2: "Have you ever had difficulty composing sentences, fear being wrong, and less motivated when speaking English?"

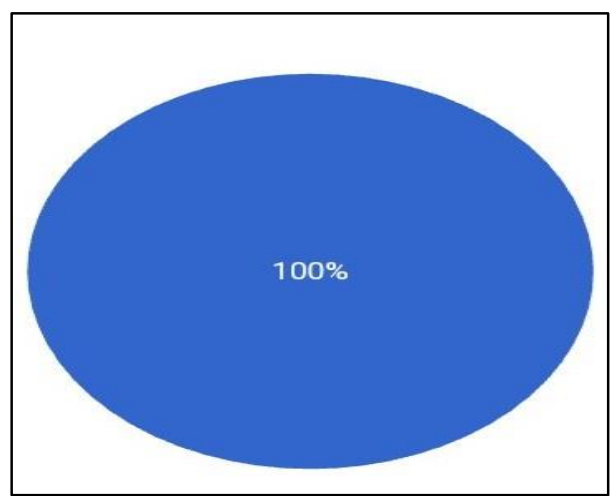

$100 \%$ or all 30 English learners feel less motivated in speaking English.

Question 3: "Do you have difficulty finding people to talk to or friends to practice speaking?"

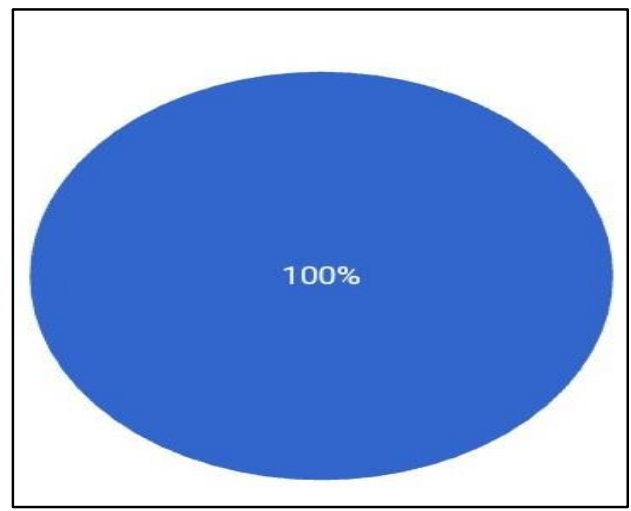

$100 \%$ or all 30 learners say that they have difficulty finding people or friends to practice speaking.

Question 4: "Do you think communicating in English face-to-face is something difficult or sometimes makes you nervous or even anxious?" 


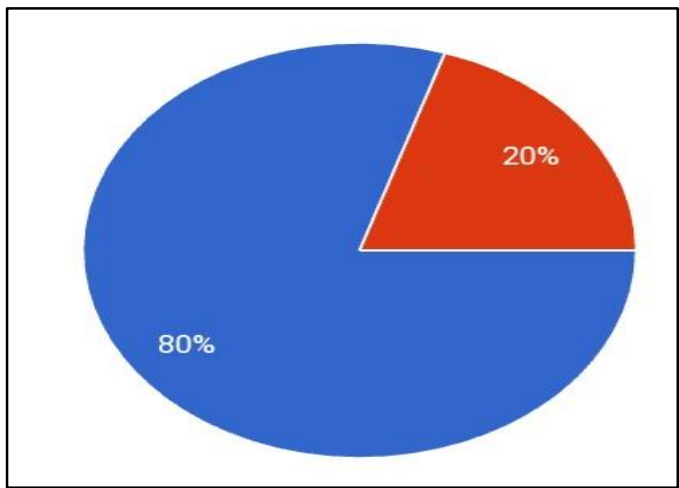

$80 \%$ of 30 English learners say that they feel anxious and difficult in communicating with the English language.

Question 5: "As technology has developed, do you think that using an application like Zoom makes you more comfortable and motivated to learn to talk to new people (native/non-native speakers) rather than face-to-face communication?

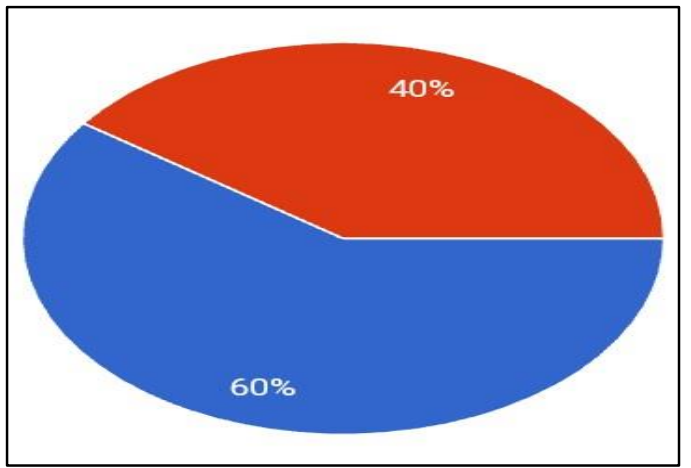

$60 \%$ of 30 English learners feel comfortable and motivated in speaking practice with other people by using Zoom Application.

Question 6: "After joining the speaking practice at the English Zoom Club and meeting lots of people to practice, do you feel zoom is a good platform to improve your speaking skills?"

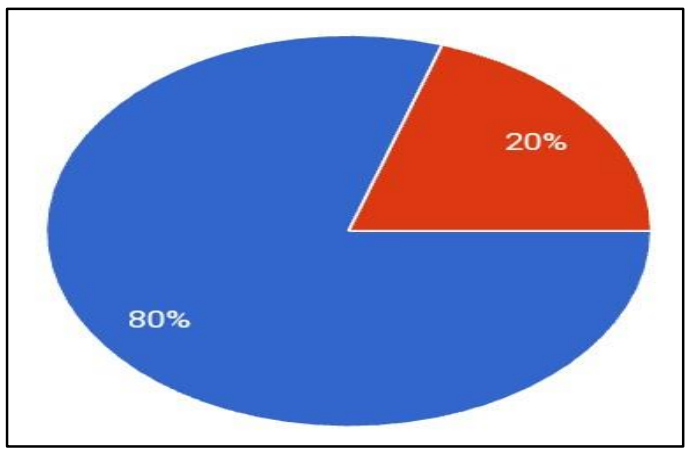

$80 \%$ of 30 English learners say that Zoom Application is a good platform to improve their speaking skills. 
Question 7: "After several times you participated in the routine of learning speaking with the zoom platform, did you feel your speaking skills improved? Or even more confident and less nervous when communicating in the English language?

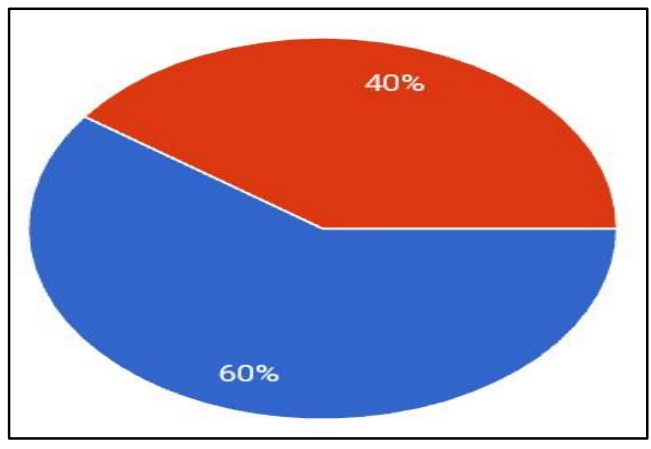

$60 \%$ of English learners say YES that with using Zoom Application they more confident in communicating with the English language.

Here is a description of the results of interviews with three English learners who can be described as follows:

\section{2) Interview}

\section{English learner 1}

The first responder is called Fransisca, she lives in Cirebon. She is an International relations student. The result of interviews conducted by the researcher can be presented as follows:

As the best conference and meeting application at this time, Zoom with its features is very fun and quite effective in increasing motivation and participation of English learners to practice speaking in English. English learners feel more exciting in practice speaking because the Zoom Application is so accessible, they only need to download the application on their PC or laptop. Zoom has breakout rooms for discussion and connotates feature which is helpful such as an arrow, control request, and highlighters. It also helps English learners because they need a flexible time to learn especially practice English speaking. Zoom Application is highly recommended for those who want to learn anywhere with new people.

The advantage of using Zoom Application is so easy to operate. The disadvantage of using Zoom Application may slow transition from one slide to another slide and be greatly influenced by the signal network.

\section{English learner 2}

The second responder is called Siska Wati, she is an English student in IKIP Siliwangi Bandung. The result of interviews conducted by the researcher can be presented as follows:

It is not difficult to operate the Zoom application also to follow the rules while in this English Zoom Club, like it or not we are required to speak in the English language. Even though this is an online activity, learners are very delighted because they can practice speaking in English without fear of making mistakes even with new people who both want to practice speaking with fun topics. Without spending a lot of money, easy access, and can be used anytime and anywhere, the zoom is highly recommended for learners, especially language learners because it can communicate with many new people.

The advantage of utilizing Zoom Application is easy to start a call and the Zoom quality of the image is quite sharp and runs smoothly. The disadvantage of utilizing Zoom Application may about the internet speed, which determines the smoothness of the online learning process. 
English learner 3 The third responder is called Khasan Mustofa. He lives in Pacitan, East Java. He is a businessman. The result of interviews conducted by the researcher can be presented as follows:

Zoom application makes it very easy for anyone who wants to join in a learning activity in the form of an online conference or meeting that can be done remotely. Learners also can find many new friends and interlocutors to practice speaking in English from various regions and various circles. Lots of features like video audio and chat help learners improve their communication skills. Communicating through the Zoom Application is not different from face-to-face communication because there are good quality audio and video, so it is highly recommended for anyone who wants to talk with new people. With the existence of learning meetings through Zoom Application which are very flexible in time, it certainly makes it easy for English learners and workers to arrange a time to practice speaking and improve their communication skills.

The advantage of applying Zoom Application in the learning process is practical to use, time and place flexibility, also the quality of the content is not different from the face-to-face learning process also many conferences or meetings are held through Zoom. The disadvantage of applying Zoom is wasteful usage of data quota.

\section{Discussion}

After finishing the online speaking practice process by Zoom Application, the participants were given the questionnaire and interview on the whole process of speaking practice. The participants are mostly students and workers with an age range from 19 years old to 30 years old. The participants decide to practice speaking online through Zoom Application for several reasons;
a. They are interested in the English language and culture but they have no friends or interlocutors to practice and improve their speaking skills.
b. They need a flexible time to learn especially practice English speaking.
c. They have difficulties in communicating or speaking English.
d. They need a good platform to help them in learning a language and communicate with other people.

Their comments on the use of Zoom as a medium of online language learning are;

a. Zoom is quite easy to start a call.

b. Zoom quality of the image is quite sharp and runs smoothly.

c. The connection is quite stable and never gets disconnected.

d. Zoom is easy to operate.

The advantage mostly mentioned by the participants about Zoom Application is that Zoom Application is familiar and commonly used by many people. Therefore they only need to download the application on their PC or laptop and it runs so smoothly, therefore no lag happens during the e-learning process. Besides, it has breakout rooms for discussion and co-annotate features which are helpful such as an arrow, control request, and highlighters.

The disadvantage mentioned by the participants in the slow transition from one slide to another slide. From the whole process of online learning, the participants who are full-time workers and students prefer to learn from 7 p.m. to 10 p.m. because they mention it is a perfect time to learn after finishing all their daily jobs and study.

The advantages of e-learning are its practical use, time and place flexibility, and the quality of the content which is not different from the face-to-face learning process also many conferences or meetings are held through zoom, for example, seminars, webinars, of course, many 
participants can join. Meanwhile, the disadvantage of e-learning is its dependency on internet connection. Internet speed determines the smoothness of the learning process. Therefore, internet connection is often considered the most crucial factor in e-learning. They mention that e-learning with Zoom Application is very beneficial unique, and different from conventional learning.

Further, most of the participants mention they will recommend online language learning and practice speaking through Zoom Application to their friends and colleagues. The questionnaire and interview are intended as an analysis tool to measure how the utilizing of Zoom application can improve English learners' motivation. The result of the questionnaire and interview can be used by other people who want to conduct online language learning by using the Zoom Ap

\section{CONCLUSION}

An application that in the beginning was created to communicate now can be beneficial for the learning process. The utilizing of Zoom Application can be beneficial for some English learners to practice speaking in the English language with other people. The sharing display feature in the application used for the webinar has fulfilled the minimum requirement to help the learning process. Zoom Application is one example of tons of similar application which can be used for online learning. After the analysis of speaking skill motivation through e-learning on Zoom, it can be concluded that Zoom Application is sufficient to be used for e-learning since it has all the required features such as sharing display, video chat, and text chat, the problem is the unstable connection has caused the process of e-learning does not run smoothly; with an almost similar feature, the connection in Zoom is quite stable. The finding indicates that Zoom is recommended to be used for e-learning. Zoom Application is necessary to support the process of e-learning. One form of interaction between or among speakers is the interactions among the participants through webinars are in the form of audio and visual. It is supported that the use of technology in the learning process can undoubtedly have a positive effect on increasing students' motivation and eventually lead them to better learning outcomes (Woodrow, 2017).

Through the improvement of the application, the e-learning using Zoom Application can be developed to wider areas. It is suggested that the learners are also very easy to access and follow online learning activities through the Zoom Application because Zoom can contain many people, this makes learners interested and motivated to improve their speaking skills and communicate with other people.

\section{ACKNOWLEDGMENTS}

Alhamdulillahirabbil 'Alamin, praise to Allah SWT who has enabled the researcher to finish this research paper. Peace and salutations are always for Rasulullah SAW. During completing the paper, the researcher obtained many help, suggestions, and motivations from many people. The researcher is overwhelmed in all humbleness and gratefulness to acknowledge her depth to her parents and friends who have prayed and supported the writing.

\section{REFERENCES}

Bainbridge, Caroline. 2005. Intrinsic and Extrinsic Motivation. Retrieved on December 1st 2009.

Baker, J. and Westrup, H. (2003). Essential speaking skills. New York: Continuum 
Chinnery, G. M. (2006). Going to the MALL: Mobile assisted language learning. Language Learning \& Technology, 10(1), 9-16. https://scholarspace.manoa.hawaii.edu/bitstream/10125/44040/1/10_01_emerging.pdf

Creswell, W. J. (2002). Research Design. Qualitative, Quantitative, and mixed $m$ e $t$ hods approaches. Second Edition. Boston: Pearson Education Inc.

David Mario Smith, J. L. (2015), "The Aragon Research Globe for Web and Video Conferencing, 2015: Focus on Platforms and Outcomes" InThe Aragon Research Globe for Web and Video Conferencing, 2015: Focus on Platforms and Outcomes. Morgan Hill: Aragon Research.

Freeman and Hasnaoui (2010), "Information and Communication Technologies (ICT): A Tool to Implement and Drive Corporate Social Responsibility (CSR)”, Hal, France.

Frydrochov Klimova, B., \& Poulova, P. (2014). ICT as a motivational tool in the learning of foreign languages. Retrieved from: http://www.europment.org/library/2014/interlaken/bypaper/EDU/EDU-06.pdf

Granito, M. \& Chernobilsky, E. (2012). The effect of technology on a student's motivation and knowledge retention. International Education Studies, 4, 116-125.

Holmes, B. \& Gardner, J. (2016). E-learning: Concepts and practice. London: Sage.

Housand, B. C., \& Housand, A. M. (2012). The role of technology in gifted students' motivation. Psychology in the Schools, 49, 706-715. doi:10.1002/pits.21629

Huang, C. S., Yang, S. J., Chiang, T. H., \& Su, A. Y. (2016). Effects of situated mobile learning approach on learning motivation and performance of EFL students. Journal of Educational Technology \& Society, 19(1), 263. https://search.proquest.com/docview/1768612513?pqorigsite $=$ gscholar

Marsono, Bambang. 2005. Motivation the Key Factor to Second Language Acquisition. Jakarta: LIA International Conference.

Morrale, S. P et al. (2001). Human Communication: Motivation, Knowledge, and Skills. USA: Wadsworth Publishing Company.

Mullamaa, K. (2010). ICT in language learning-benefits and methodological implications. $\begin{array}{llll}\text { International education } & 38 .\end{array}$ http://www.ccsenet.org/journal/index.php/ies/article/viewFile/4965/4131/

Nor, S., Baharudin, A., Murad, M., et al. (2013), "Challenges of Adult Learners: A Case Study of Full Time Postgraduates Students” Procedia - Social and Behavioral Sciences, 90, (InCULT 2012), 772-781.

Sanacore, J. (2008). Turning reluctant learners into inspired learners. Clearing House: A Journal of Educational Strategies, Issues and Ideas, 82(1), 40-44.

Song, D., \& Bonk, C. J. (2016). Motivational factors in self-directed informal learning from online learning resources. Cogent Education, 3(1), 1205838. http://www.publicationshare.com/pdfs/Cogent_Ed_Song_Bonk_Motiv_Self Directed_Informal.pdf

Susilawati, Ai.2007. The Effect of Learning Strategy Training : Socio Affective Strategy in Improving speaking. University of Lampung (unpublished script). Bandar Lampung.

Terrell, S. S. (2011). Integrating online tools to motivate young English language learners to practice English outside the classroom. International Journal of Computer-Assisted Language Learning and Teaching (IJCALLT), 1(2), 16-24.

Use Zoom for Effective Online Lessons. [Electronic resource]. - Access mode:https://teach.englishsuccessacademy.com/use-zoom/

Utami, Nuzulul Dwi. 2012 An Analysis on Students' Effort to Improve Speaking Skill. Journal: Tanjung Pura University. Pontianak.

Woodrow, L. (2017) Motivation in Language Learning. In: Breeze R., Sancho Guinda C. (eds) Essential Competencies for English-medium University Teaching. Educational 
Linguistics,vol27.Springer,Cham. https://link.springer.com/content/pdf/10.1007\%2F9783-319-40956-6_16.pdf 